Marquette University

e-Publications@Marquette

Social and Cultural Sciences Faculty Research and

Publications

Social and Cultural Sciences, Department of

$1-1-2013$

\title{
Connectedness and the Sociopolitical Involvement of Same-Gender-Loving Black Men
}

Juan Battle

The Graduate Center, City University of New York

Angelique Harris

Marquette University, angelique.harris@marquette.edu

Accepted version. Men and Masculinities, Vol.16, No. 2 (2013): 260-267. DOI. (C) 2013 by SAGE

Publications. Used with permission. 
Marquette University

\section{e-Publications@Marquette}

\section{Social and Cultural Sciences Faculty Research and Publications/Department of Social and Cultural Sciences}

This paper is NOT THE PUBLISHED VERSION; but the author's final, peer-reviewed manuscript. The published version may be accessed by following the link in the citation below.

Men and Masculinities, Vol. 16, No. 2 (2013): 260-267. DOI. This article is (C SAGE Publications and permission has been granted for this version to appear in e-Publications@Marquette. SAGE Publications does not grant permission for this article to be further copied/distributed or hosted elsewhere without the express permission from SAGE Publications.

\section{Connectedness and the Sociopolitical Involvement of Same-Gender-Loving Black} Men

Angelique Harris

Department of Social and Cultural Sciences, Marquette University, Milwaukee WI

\section{Abstract}

Employing a national sample of over 800 same-gender-loving black men, we explore the relative impact of community-level support/comfort and the importance of sexual orientation and racial identity on two dependent variables - sociopolitical involvement within lesbian, gay, bisexual, and transgender (LGBT) communities and sociopolitical involvement within people of color (POC) communities. Findings indicate that feelings of connectedness to LBGT communities is the most important predictor of sociopolitical involvement within both LGBT and POC communities; while, counterintuitively, being comfortable within the LGBT community had a negative impact on the sociopolitical involvement of these men. Further, the impact of the importance of identity was negligible. 
Keywords

black gay men, community engagement, civil engagement, sociopolitical involvement

\section{Introduction}

Sociopolitical involvement is an understudied subset of civic engagement that examines people's connectedness to the political and social life of their community and it is important for both the individual's sense of self and his or her connectedness to their community. Yet, many individuals feel unaccepted and marginalized within their social and cultural groups. It is particularly problematic when this marginalization occurs within groups that experience multiple forms of oppression (Reynolds and Pope 1991). As a group who has historically faced race, class, and sexuality-based oppression and marginalization, black same-gender-loving (SGL) men will be used to examine the impact that community connectedness has on sociopolitical involvement. Through survey data collected from over 800 black men who took part in the Social Justice Sexuality Project Survey-a survey that measures the experiences of lesbian, gay, bisexual, and transgender (LGBT) people of color (POC) -this article explores the sociopolitical involvement of SGL black men in both the LGBT communities and with communities of color.

\section{Literature Review}

Civic engagement has been examined in relation to a number of variables, including race, gender, income, education, geographic location, and, most notably, age (Putnam 2000; Sander and Putnam 2006; Verba, Schlozman, and Brady 1995). Research indicates that in the United States, blacks and whites have the highest levels of civic engagement as compared to Asian Americans and Latinos (Verba, Schlozman, and Brady 1995). More specifically, blacks - as compared to their white counterparts - spend significantly more hours volunteering for political campaigns and are more likely to participate in issue-based activities, such as basic human needs, education, civil rights, and, in particular, criminal justice or drug issues (Verba, Schlozman, and Brady 1995). Regarding gender, women are more likely to be involved in civic activities than are men (Campbell 2009; Verba, Schlozman, and Brady 1995). Levels of civic engagement greatly increased with both income and education (Verba, Schlozman, and Brady 1995); however, research argues that the greatest determinant for civic engagement is age cohort (Galston and Lopez, 2006; Sander and Putnam 2006; Putnam 2000). Activities such as volunteering for organizations, voting, and even church attendance are heavily determined by age cohort, with older Americans participating in more of these activities than younger ones (Galston and Lopez 2006; Sander and Putnam 2006). However, research does not specifically examine civic engagement among black gay men. This project aims to answer the question: what are the motivating factors associated with sociopolitical involvement among black SGL men?

\section{Method}

The data used in this study come from a 2010 survey administered by the Social Justice Sexuality Project. The purpose of this project was to collect data on the experiences of LGBT POC concerning the following five themes: identity (both racial and sexual), physical/mental health, family, religion/spirituality, and sociopolitical involvement. Data were collected from over 5,000 respondents 
throughout the United States and Puerto Rico. This article focuses on the subset of 833 men who identified as black.

The black men within this sample were between 13 and 81 years of age, with a mean age of $37 \mathrm{~A}$ little over one-half of the respondents identified as single (60 percent) and only 22 percent are parents. Most respondents lived in urban areas ( 77 percent) and 38 percent lived in the southern part of the United States. The average respondent identified as being politically liberal. The level of education among the respondents ranged from less than high school (two percent) to graduate/professional school (20 percent). A majority of the respondents (28 percent) reported having at least some college education, with 22 percent reporting having a bachelor's degree. The reported household income ranged from under $\$ 8,500$ (nine percent) to over $\$ 100,000$ per year (10 percent).

\section{Measures}

This article focuses on the correlates of sociopolitical involvement among a sample of black SGL men in both LGBT and POC organizations and events. There were 11 measures (see Table 1).

Demographic variables included age, sexual orientation, relationship status, having children, born in the United States or not, residing in an urban, suburban, or rural area, being a resident of the southern part of the United States, political views, education, and income.

LGBT sociopolitical involvement $(\alpha=.751$ ) consisted of the prompt "Thinking about LGBT groups, organizations, and activities in general, during the past 12 months, how have you: (Check one box per question)" followed by six items: participated in political events, participated in social or cultural events, read newspapers or magazines, used the Internet, received goods and/or services, and donated money to an organization. Items were scored on six-point Likert-type scales where $1=$ never and 6 = more than once $a$ week.

POC sociopolitical involvement $(\alpha=.789)$ consisted of the prompt "Thinking about groups, organizations, and activities for people of color, during the past 12 months, how often have you: (Check one box per question)" followed by the same six items as above.

Connection to LGBT Community $(\alpha=.787$ ) consisted of three items (e.g., "I feel a bond with other LGBT people") scored on six-point Likert-type scales where 1 = strongly disagree and $6=$ strongly agree.

Outness ( $\alpha=.900$ ) was a six-point scale about outness to various groups (e.g., family, religious community) and items were scored on five-point Likert-type scales where $1=$ none to $5=$ all.

Family support consisted of one item: "As a LGBT person, how much do you now feel supported by your family?" with the seven-point Likert-type scale ranging from $1=$ not at all supported to $7=$ they don't know I'm LGBT.

Comfort in LGBT communities consisted of the item "How often have you felt uncomfortable in your LGBT community because of your race and ethnicity?" and comfort in racial communities consisted of the item "How often have you felt uncomfortable in your racial or ethnic community because of your sexual orientation?" Both items had six-point Likert-type scales from $1=$ always to $6=$ never. 
Sexual identity importance consisted of the item "Do you feel that your sexual orientation is an important part of your identity?" and racial identity importance consisted of the item "Do you feel that your racial or ethnic status is an important part of your identity?" Both items were scored with sixpoint Likert-type scales where $1=$ not at all important to $6=$ extremely important.

\section{Models}

In order to explore the effects of identity and community on the LGBT and POC sociopolitical involvement of black SGL men, four models were run. The first examined community connectedness (connection to LGBT community, outness, family support, comfort in LGBT communities, and comfort in racial communities) on the level of LGBT sociopolitical involvement. The second model examined community connectedness and identity (sexual identity importance, racial identity importance, and sexual orientation) on the level of LGBT sociopolitical involvement. The third model examined community connectedness on the level of POC sociopolitical involvement. Finally, the fourth model examined community connectedness and identity on the level of POC sociopolitical involvement.

\section{Results}

For the first two models of the multivariate analyses, LGBT sociopolitical involvement was the dependent variable (see Table 2). Men who felt more connected to LGBT communities and were out to more people had higher levels of LGBT sociopolitical involvement. However, quite surprisingly and somewhat counterintuitively, the greater the comfort these men had with LGBT communities, the lower their LGBT sociopolitical involvement. Family support and comfort in racial communities had no impact on LGBT sociopolitical involvement. All of these relationships held when the importance of identity measures was introduced into the models (see model 2), as well as when several demographic variables were included (see footnote on Table 2 ). 
Table I. Means, Standard Deviants, Ranges, and Description of Variables for Black Men $(N=833)$.

\begin{tabular}{|c|c|c|c|c|}
\hline Variable & M & SD & Range & Description: Variable Label \\
\hline \multicolumn{5}{|l|}{ Dependent variable } \\
\hline $\begin{array}{l}\text { LGBT sociopolitical } \\
\text { involvement }(\alpha=.751)\end{array}$ & 3.39 & 0.98 & $1-6$ & $\begin{array}{l}\text { Involvement in groups, organizations, and } \\
\text { activities for LGBT }\end{array}$ \\
\hline $\begin{array}{l}\text { POC sociopolitical } \\
\text { involvement }(\alpha=.789)\end{array}$ & 3.16 & 1.09 & $1-6$ & $\begin{array}{l}\text { Involvement in groups, organizations, and } \\
\text { activities for POC }\end{array}$ \\
\hline \multicolumn{5}{|l|}{ Community } \\
\hline $\begin{array}{l}\text { Connected to LGBT } \\
\text { community }(\alpha=.787)\end{array}$ & 3.97 & 1.33 & $1-6$ & Connected to LGBT community/people \\
\hline Outness $(\alpha=.900)$ & 3.55 & 1.17 & $1-5$ & $\begin{array}{l}\text { How many people within the following } \\
\text { communities are you "out" to: family, } \\
\text { friends, religious community, } \\
\text { coworkers, etc. }\end{array}$ \\
\hline Family support & 4.31 & 1.67 & $1-6$ & $\begin{array}{l}\text { As a LGBT person, how much do you now } \\
\text { feel supported by your family }\end{array}$ \\
\hline $\begin{array}{l}\text { Comfort in LGBT } \\
\text { communities }\end{array}$ & 3.99 & 1.59 & $1-6$ & $\begin{array}{l}\text { How often have you felt uncomfortable in } \\
\text { your LGBT community because of your } \\
\text { race or ethnicity }\end{array}$ \\
\hline $\begin{array}{l}\text { Comfort in racial } \\
\text { communities }\end{array}$ & 3.56 & 1.56 & $1-6$ & $\begin{array}{l}\text { How often have you felt uncomfortable in } \\
\text { your racial or ethnic community } \\
\text { because of your sexual identity }\end{array}$ \\
\hline \multicolumn{5}{|r|}{ 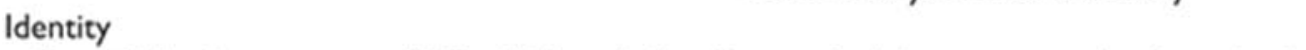 } \\
\hline $\begin{array}{l}\text { Sexual identity } \\
\text { importance }\end{array}$ & 4.47 & 1.61 & $1-6$ & $\begin{array}{l}\text { Do you feel that your sexual orientation is } \\
\text { an important part of your identity? }\end{array}$ \\
\hline $\begin{array}{l}\text { Racial identity } \\
\text { importance }\end{array}$ & 4.50 & 1.61 & $1-6$ & $\begin{array}{l}\text { Do you feel that your racial or ethnic } \\
\text { status is an important part of your } \\
\text { identity? }\end{array}$ \\
\hline
\end{tabular}

Note. LGBT = lesbian, gay, bisexual, and transgender; POC $=$ people of color. 
Table 2. Unstandardized Regression Coefficients for the LGBT and POC Sociopolitical Involvement among Black Men ( $\beta$ s in parentheses).

\begin{tabular}{|c|c|c|c|c|}
\hline \multirow[b]{4}{*}{ Independent Variables } & \multicolumn{4}{|c|}{ Dependent Variables } \\
\hline & \multirow{2}{*}{\multicolumn{2}{|c|}{$\begin{array}{c}\text { LGBT Sociopolitical Involvement } \\
\qquad N=833\end{array}$}} & \multirow{2}{*}{\multicolumn{2}{|c|}{$\begin{array}{c}\text { POC Sociopolitical Involvement } \\
N=833\end{array}$}} \\
\hline & & & & \\
\hline & Model I & Model $2^{\mathrm{a}}$ & Model 3 & Model $4^{2}$ \\
\hline \multicolumn{5}{|l|}{ Community } \\
\hline $\begin{array}{l}\text { Connected to } \\
\text { LGBT community }\end{array}$ & $.230^{* 11 \%}(.310)$ & $.225^{* 10 \%}(.303)$ & $.173^{\text {wopk }}(.212)$ & $.167^{* 0 \% *}(.204)$ \\
\hline Outness & $.165^{* * * *}(.195)$ & $.163^{* 10 \%}(.193)$ & $.050^{\dagger}(.054)$ & $.049^{\dagger}(.053)$ \\
\hline Family support & $.000(.000)$ & $-.004(-.006)$ & $.037^{\dagger}(.057)$ & $.032^{\dagger}(.049)$ \\
\hline $\begin{array}{l}\text { Comfort in LGBT } \\
\text { communities }\end{array}$ & $-.052^{*}(-.083)$ & $-.050 *(-.080)$ & $-.037^{\dagger}(-.054)$ & $-.035^{\dagger}(-.050)$ \\
\hline $\begin{array}{l}\text { Comfort in racial } \\
\text { communities }\end{array}$ & $.011(.017)$ & $.015(.024)$ & $.046^{\dagger}(.066)$ & $.052 *(.075)$ \\
\hline \multicolumn{5}{|l|}{ Identity } \\
\hline $\begin{array}{l}\text { Sexual identity } \\
\text { importance }\end{array}$ & & $.002(.004)$ & & $-.001(-.001)$ \\
\hline $\begin{array}{l}\text { Racial identity } \\
\text { importance }\end{array}$ & & $.021(.035)$ & & $.031(.045)$ \\
\hline Heterosexual & & $.015(.002)$ & & $.029(.033)$ \\
\hline Constant & $2.063^{\text {*w* }}$ & $1.974^{*}$ & $2.116 \%$ *\%o & 1.999 *1\%k \\
\hline Adjusted $R^{2}$ & .166 & .165 & .060 & .058 \\
\hline
\end{tabular}

Note. LGBT = lesbian, gay, bisexual, and transgender; POC $=$ people of color.

'The following demographic variables were included: single, has ever parented, age, foreign-born, big city resident, south resident, political views, education, and income. However, except for has ever parented, none were significant and none impacted the above results.

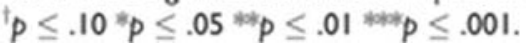

When POC sociopolitical involvement was the dependent variable (models 3 and 4), similar results emerged. This may not be too surprising, given that the men in the sample represent participation in both LGBT communities and POC communities. Therefore, as with LGBT sociopolitical involvement, when examining POC sociopolitical involvement for the black men in this study, connection to LGBT communities had a positive impact; however, neither comfort in LGBT communities nor family support had an impact (see model 3). However, differences also emerged. For example, being out to more people was not statistically significant. Interestingly, feeling more comfortable in their racial communities did not increase the POC sociopolitical involvement of the men in this sample. Nonetheless, as with LGBT sociopolitical involvement, all of these relationships held when the importance of identity measures was introduced into the models (see model 4), as well as when several demographic variables were included (see footnote on Table 2), with the exception of comfort in racial communities. According to the data, the black men in the sample were more likely to be involved with POC communities if they felt comfortable within their racial communities.

Finally, it is worth noting that while comfort in racial communities was not a significant predictor of LGBT sociopolitical involvement (see model 2), it was positively significant for POC sociopolitical involvement (see model 4). Similarly, the importance of racial identity was a significant predictor of LGBT sociopolitical involvement. 


\section{Discussion}

The data presented in this article show that the connectedness to LGBT communities that this sample of SGL black men experience is the most important indicator for their sociopolitical involvement within both LGBT and POC communities. Organizers, service providers, and cultural producers, particularly those within POC communities, should note the importance of LGBT communities for SGL black men. These organizations may want to encourage LGBT communities to be more open and accepting to SGL black men as it will likely increase the social and political participation of these men within POC communities and groups.

The findings here contradict research arguing that demographic variables such as age, income, and education significantly impact civic engagement (Sander and Putnam 2006; Putnam 2000; Verba, Schlozman, and Brady 1995). These contradictions could be due to the specific measures used in this study, such as our focus on sociopolitical involvement instead of the focus of previous research on civic engagement, which ignores the social aspects of community involvement. Additionally, research has not been collected on SGL black men, as such, the demographic characteristics of this population may vary from what literature notes. Also, our study participants may be more socially and civically active in their communities considering that the sample was primarily found within LGBT and POC sociocultural events. It is likely that these men are not truly representative of the general SGL black male population, but of those who are involved in sociopolitical events. This sample population may be more likely to participate in sociocultural events and activities or may see this participation as being more vital to their identity development than men who do not attend these events.

It was somewhat unexpected that the greater levels of comfort in LGBT communities would have a negative impact on both measures of sociopolitical involvement. Possibly, these men are active in these communities in an effort to seek out community support either when they first come out, in an attempt to seek out new friends, or even when they move to a new location. Once they feel more comfortable in these communities, they may feel less likely to be engaged in these communities. This finding may also be reflective of research purporting that civic engagement is an important coping mechanism for those facing multiple levels of minority-based stress (Balsam et al. 2011; Poynter and Washington 2005). In short, when SGL black men feel alienated from LGBT communities, their coping strategy may be to become all the more sociopolitically involved.

The data presented in this project may help explain the importance of LGBT communities for SGL black men. This study focused on sociopolitical involvement and connectedness to LGBT communities, so it did not inquire about respondents' connectedness or feelings of belonging to POC communities; however, it did assess comfort in racial communities based on their sexual orientation. Thus, it is unlikely that the results of this study would be replicated if participants were recruited in POC spaces. Future research should examine whether feelings of belonging within POC communities would be as important as feelings of belonging within LGBT communities in impacting engagement in LGBT POC communities. This article highlights the need for more data collection examining the demographic features of SGL black men, and LGBT POC in general, so researchers can better examine not only sexual identity and/or racial/ethnic identity but the impact that they have on one's sociopolitical involvement. Future research should also examine the influence of community connectedness to both activist and non-activist volunteerism within both POC and LGBT communities. Additionally, longitudinal data 
projects that examine demographic characteristics and changes in sociopolitical involvement are needed, for example, how the sociopolitical involvement of these men changes as they age.

\section{Declaration of Conflicting Interests}

The author(s) declared no potential conflicts of interest with respect to the research, authorship, and/or publication of this article.

\section{Funding}

The author(s) received no financial support for the research, authorship, and/or publication of this article.

\section{References}

Balsam, K. M., Molina, Y., Beadnell, B., Simoni, J., Walters, K.. 2011. "Measuring Multiple Minority Stress: The LGBT People of Color Microaggressions Scale." Cultural Diversity and Ethnic Minority Psychology 17:163-74.

Campbell, D. E. 2009. "Civic Engagement and Education: An Empirical Test of the Sorting Model." American Journal of Political Science 53:771-86.

Galston, W. A., Lopez, M.. 2006. "Civic Engagement in the United States." In Civic Engagement and the Baby Boomer Generation: Research, Policy, and Practice, edited by Wilson, L. B., Simson, S. P., 3-19. Binghamton, NY: Haworth.

Poynter, K. J., Washington, J.. 2005. "Multiple Identities: Creating Community on Campus for LGBT Students." New Directions for Student Services 111:41-47.

Putnam, R. 2000. Bowling Alone: The Collapse and Revival of American Community. New York, NY: Simon \& Schuster.

Reynolds, A. L., Pope, R. L.. 1991. “The Complexities of Diversity: Exploring Multiple Oppressions.” Journal of Counseling \& Development 70:174-80.

Sander, T. H., Putnam, R. D.. 2006. "Social Capital and Civic Engagement of Individuals over Age Fifty in the United States." In Civic Engagement and the Baby Boomer Generation: Research, Policy, and Practice Perspectives, edited by Wilson, L. B., Simson, S. P., 21-39. Binghamton, NY: Haworth.

Verba, S., Schlozman, K. L., Brady, H. E.. 1995. Voice and Equality: Civic Voluntarism in American Politics. Cambridge, MA: Harvard University Press. 